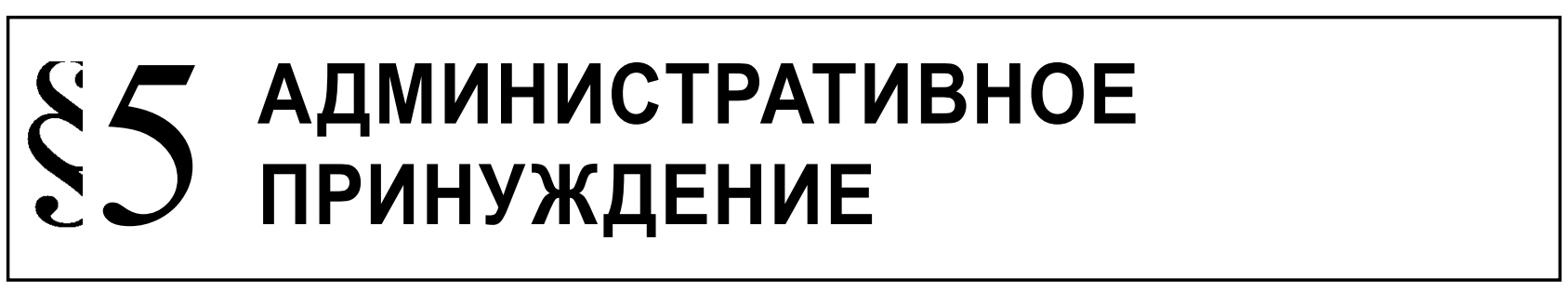

Шутилина O.A.

\title{
ВОПРОСЫ ПРИМЕНЕНИЯ ПРИВОДА КАК МЕРЫ ОБЕСПЕЧЕНИЯ ПРОИЗВОДСТВА ПО ДЕЛАМ ОБ АДМИНИСТРАТИВНЫХ ПРАВОНАРУШЕНИЯХ
}

\begin{abstract}
Аннотация: В статье исследуются правовая природа, сущностные характеристики, а также законодательные нормы, регулирующие вопросы основания применения привода. Привод как меру обеспечения производства по делам об административных правонарушениях необходимо отличать от мер административного принуждения, которые не связаны с совершением правонарушения и носят предупредительный характер. Эта мера обеспечения производства по делам об административных правонарушениях по своей правовой природе, определяемой их целевой направленностью, не является санкцией, а вспомогательным средством принудительного воздействия, с помощью которого обеспечивается нормальный порядок производства. Методологическую основу научной статьи составили общенаучные методы познания, в том числе: метод системного анализа, метод комплексного подхода, сравнительно-правовой, формально-логический, системно-структурный, формально-юридический, юридико-технический методы исследования. Автор отмечает, что определение рассматриваемой меры обеспечения производства по делам об административных правонарушениях не в полном объеме учитывает её сущностные характеристики. В этой связи определение меры обеспечения производства по делам об административных правонарушениях, представляющее собой сложное административно-правовое явление, возможно лишь на основе выявления присущих ей неотъемлемых признаков. Автор подчеркивает, что неизменным остается положение о том, что допустимые по Конституции РФ И международным актам ограничения прав и свобод человека должны быть соразмерны по своему содержанию и объему с охраняемыми интересами и соответствовать общим целям, задачам и принципам применения привода как меры обеспечения производства по делам об административных правонарушениях.
\end{abstract}

Ключевые слова: мера обеспечения производства, административное правонарушение, законодательство, срок, кодекс, права и свободы, личность, основание административной ответственности, принудительный привод, процессуальный акт.

П ривод является самостоятельной мерой обеспечения производства по делу об административном правонарушении, закрепленной в КоАП РФ. Приводу в административно-правовой науке не было уделено так много внимания, как административному задержанию и доставлению. Тем не менее, привод явился объектом научных разработок целого ряда ученых ${ }^{1}$. Этим в определенной

1 См.: Тюрин В.А., Куракин А.В. Меры административного пресечения // Юрист. 2001. № 10. С. 63.; Попугаев Ю.И. Административно-процессуальные меры, применяемые в связи с совершением правонарушения (по материалам деятельности советской милиции) : Автореф. дис. ... канд.

степени и объясняется отсутствие в настоящее время единства мнений относительно юридической природы и содержания исследуемой меры.

Изучение этого вопроса показало что, эта мера административно-правового принуждения законодателем в полном объеме не определена. В ст. 27.15 КоАП РФ есть указание на то, что привод осуществляется органом внутренних дел (полицией) или органом, уполномоченным на осуществление

юрид. наук. М., С. 20 - 23.; Помогалова Ю.В. Административное задержание, доставление и привод в системе мер административного принуждения: Дис. ... канд. юрид. наук. Саратов. 2005. С. 159. 
функций по принудительному исполнению исполнительных документов на основании определения судьи, органа, должностного лица, рассматривающих дело об административном правонарушении, в порядке, установленном федеральным органом исполнительной власти.

Необходимо обратить внимание на то, что содержание привода как меры обеспечения производства не раскрывается не только в законе, но и в комментариях. Так, в Комментарии КоАП РФ под редакцией А.Б. Агапова об этом ничего не сказано 2 .

Принятие в соответствии со статьей 27.15 КоАП РФ Инструкции о порядке осуществления привода ${ }^{3}$ привело к положительному результату - существенному усилению правовых гарантий законности при применении такой меры административного принуждения, как привод.

Сравнительный анализ ч. 2 ст. 27.15, ч. 3 ст. 29.4 , п.8 ч.1 ст.29.7 КоАП РФ, а также Инструкции о порядке осуществления привода позволяет сделать вывод, что указанная мера обеспечения производства по делам об административных правонарушениях является принудительной мерой, применяемой к лицам, в отношении которых ведется производство по делу об административном правонарушении, их законным представителям (когда при рассмотрении дела их присутствие обязательно), в случае их неявки без уважительной причины по вызову судьи, органов и должностных лиц, уполномоченных рассматривать дело.

Целью применения привода является принудительное обеспечение процессуальных действий ввиду невозможности их заочного производства.

На наш взгляд, нельзя согласиться с точкой зрения Ю.В. Помогаловой, выделяющей в качестве одной из целей применения привода, «пресечение уклонения правонарушителя от ответственности перед законом» ${ }^{4}$ поскольку данная мера применяется не только к лицам, в отношении которых ведется производство по делу об административном правонарушении, но и к законным пред-

\footnotetext{
2 См.: Комментарий к Кодексу Российской Федерации об административных правонарушениях (постатейный) / под редакцией А. Б. Агапова. М., 2002. С. 1128.

3 См.: Инструкция о порядке осуществления привода: приказ МВД РФ от 21 июня 2003 г. № 438 // Бюллетень. 2003. № 47.

4 См.: Помогалова Ю.В. Административное задержание, доставление и привод в системе мер административного принуждения: Дис. ... канд. юрид. наук. Саратов. 2005. С. 161.
}

ставителям несовершеннолетнего лица, а также к свидетелям административного правонарушения, не привлекающимся к административной ответственности.

Представляет значительный интерес трактовка понятия привода к следственно-судебным органам как разновидности принуждения: «Привод к следствию или суду допускается в отношении обвиняемых, не явившихся в срок без законных причин по письменной повестке, и в отношении свидетелей - если они не явятся, без законных причин, после двукратного призыва повесткой» 5 . При широком толковании этого понятия привод можно отнести к разновидности полицейского ареста (привод выполняется органом внутренних дел (п. 2 ч. 2 ст. 27.15 КоАП РФ)).

Таким образом, необходимо четко сформулировать понятие привода, поскольку ни одно из имеющихся в административно-правовой литературе определений привода до сих пор не нашло своего нормативно-правового закрепления.

Привод как меру обеспечения производства по делам об административных правонарушениях необходимо отличать от мер административного принуждения, которые не связаны с совершением правонарушения и носят предупредительный характер. Примером может служить доставление сотрудниками полиции граждан, в состоянии алкогольного, наркотического или иного токсического опьянения, в медицинские организации, либо в служебное помещение территориального органа или подразделения полиции, если есть основания предполагать, что они могут причинить вред жизни и здоровью граждан, нанести ущерб имуществу (п. 14 ч. 1 ст. 13 Федерального закона от 07.02.2011 N 3-Ф $\left.3^{6}\right)$.

Следует согласится с точкой зрения Ю.В. Помогаловой, А.Ю. Соколова, что привод в административно-юрисдикционном процессе выступает единственной мерой обеспечения по делу об административном правонарушении, который не может применяться на стадии возбуждения дела об административном правонарушении ${ }^{7}$ В то же

\footnotetext{
5 См.: Ильяшенко А.Н. Арест как мера государственного принуждения: теоретические и исторические аспекты // Общество и право. 2008. N 2. С. 7.

6 См.: Федеральный закон Рос. Федерации от 07 февраля 2011 г. N 3-Ф3 «О полиции» // Рос. Газ. 2011. 8 фев. № 5401.

См.: Помогалова Ю.В. Административное задержание, доставление и привод в системе мер административного принуждения: Дис. ... канд. юрид. наук. Саратов. 2005. С.
} 
время следует подчеркнуть, что отсутствие полномочий применять привод у компетентных должностных лиц, производящих административное расследование по определенным категориям дел достаточно часто делает невозможным эффективное производство по делам об административных правонарушениях.

Процессуальным основанием привода выступает определение - процессуальный акт, выносимый компетентным органом, должностным лицом. Небесспорной представляется точка зрения А.С. Дугенеца, о том, что принятие решения об осуществлении привода является исключительной прерогативой судьи ${ }^{8}$. Определение о приводе выносится судьей, органом, должностным лицом, рассматривающими дело об административном правонарушении (ч. 2 ст. 27.15 КоАП РФ).

В соответствии с п.3 Инструкции о порядке осуществления привода, привод лица, не достигшего возраста шестнадцати лет, производится с уведомлением его законных представителей, либо администрации по месту его работы или учебы. «Иной порядок привода несовершеннолетних допускается лишь в случаях, когда это оговорено в определении о приводе» ${ }^{9}$. Следует отметить, что эта Инструкция не указывает, что следует понимать под иным порядком привода несовершеннолетнего. Следовательно, необходимо уточнение понятия «иной порядок привода несовершеннолетних» и порядка применения его практической деятельности уполномоченных органов.

Осуществлению привода всегда должно предшествовать направление уведомления о времени и месте рассмотрения дела необходимому участнику административного процесса для рассмотрения дела об административном правонарушении с его участием. На наш взгляд, из-за отсутствия нормативного регулирования, данный порядок не всегда соблюдается, что существенно ограничивает права и законные интересы подвергаемых приводу лиц. Судья, орган,

165.; Соколов А.Ю. Меры обеспечения производства по делам об административных правонарушениях в системе мер административного принуждения: Дис. ... док. юрид. наук. Саратов, 2012. С. 222.

8 См.: Дугенец А.С. Административно-юрисдикционный процесс: монография. М., 2003. С. 143.

9 См.: Инструкция о порядке осуществления привода: приказ МВД РФ от 21 июня 2003 г. № 438 // Бюллетень. 2003. № 47. должностное лицо, выносящее определение о приводе, должно проверить факт реального извещения лица о времени и месте рассмотрения дела и причины неявки.

К уважительным причинам можно отнести тяжелую болезнь, невозможность обеспечить на время отсутствия присмотр за малолетними детьми и т.п. Привод не может проводиться в ночное время, кроме случаев, не терпящих отлагательства (возможность совершения новых правонарушений, утрата доказательств и т.д.). Таким образом, решению о приводе должна предшествовать проверка причин неявки вызываемого лица: получило ли оно вызов, не имеется ли данных о его болезни, не находится ли оно в командировке, нет ли иных причин, объективно препятствующих его явке по вызову. И только после выяснения обстоятельств неявки лица уполномоченный орган имеет право вынести определение о приводе.

Наибольшее число нарушений прав личности допускают сотрудники полиции при содержании в органах внутренних дел лиц, в отношении которых осуществлен привод. Ни законодательством, ни ведомственными нормативными актами не урегулировано, где и в течение какого срока может содержаться лицо, подвергнутое приводу. Такой же точки зрения придерживается и Д.Н. Бахрах ${ }^{10}$. Следовательно, с целью обеспечения прав и законных интересов лица, подвергнутого приводу, было бы целесообразно закрепить в КоАП РФ положение о том, что привод лица осуществляется на срок, необходимый для проведения процессуальных действий, ради которых и был произведен привод.

На наш взгляд, нарушением прав лица, уклоняющегося от явки в суд, является помещение этого лица в изолятор временного содержания, комнату для задержанных в административном порядке или в приемник для административно арестованных, поскольку данная мера применяется не только к лицам, в отношении которых ведется производство по делу об административном правонарушении, но и к законным представителям несовершеннолетнего лица, а также к свидетелям административного правонарушения, не привлекающимся к административной ответственности. Так, А. И. Дворяк указывает о необходимости законодательного закрепления порядка применения привода, предусматривающего пред-

10 См.: Бахрах Д.Н. Административное право России: учебник. М., 2010. С. 528. 
варительный вызов в соответствующий орган и в определенное время лица, подвергаемого приводу, а также проверки уважительности причины его неявки ${ }^{11}$.

Нельзя не согласиться с Ю.И. Попугаевым, который утверждает, что «содержащееся в соответствующем органе, подвергнутое приводу, лицо находится в положении административно задержанного лица» ${ }^{12}$. Из этого следует, что если лицо претерпевает практически такие же правоограничения, что и лицо, содержащееся в качестве административно задержанного, то следовало бы ограничить срок пребывания данного лица тремя часами, так же как и для административного задержания в соответствии с ч.1 ст. 27.5. КоАП РФ.

На наш взгляд, необходимо обратить внимание на то, что в Инструкции, регулирующей порядок применения привода, как для целей обеспечения производства по делам об административных правонарушениях, так и для уголовного судопроизводства, не закреплен на законодательном уровне перечень лиц, не подлежащих приводу. В связи с этим, нуждается в дополнении ст. 27.15 КоАП РФ положениями, закрепляющими перечень лиц, к которым не может быть применен привод.

Подводя итог изложенному, можно сделать вывод о том, что пробелы в законодательном регулировании некоторых аспектов применения привода, безусловно, являются первопричиной неоправданного ограничения законных прав и интересов физических лиц. Сложившуюся в правовом регулировании привода ситуацию возможно изменить только путем комплексного решения возникающих в этой связи вопросов на законодательном уровне.

\section{Библиография:}

1. Бахрах Д.Н. Административное право России. М.: Эксмо, 2010. 607 с.

2. Дворяк А.И. Меры административно-процессуального пресечения, применяемые милицией. М., 1997.

3. Дугенец А.С. Административно-юрисдикционный процесс: Монография. М.: Инфра-М, 2003. С. 143.

4. Ильяшенко А.Н. Арест как мера государственного принуждения: теоретические и исторические аспекты // Общество и право. 2008. N 2. С. 7.

5. Костенников М.В., Куракин А.В. Актуальные проблемы административно-правового регулирования. М.: Маросейка, 2010. Т. 1. 496 с.

6. Куракин А.В. Актуальные проблемы науки административного права. М.: Маросейка, 2011. 573 с.

7. Помогалова Ю.В. Административное задержание, доставление и привод в системе мер административного принуждения. Саратов. 2005.

8. Попугаев Ю.И. Административно-процессуальные меры, применяемые в связи с совершением правонарушения (по материалам деятельности советской милиции). М., 1991.

9. Соколов А.Ю. Меры обеспечения производства по делам об административных правонарушениях в системе мер административного принуждения. Саратов, 2012.

10. Тюрин В.А., Куракин А.В. Меры административного пресечения // Юрист. 2001. № 10. С. 63.

11. Купреев С.С. Правовая ответственность государства при применении мер обеспечения производства по делам об административных правонарушениях // Административное и муниципальное право. - 2010. - 4. - С. 70 - 75.

\section{References (transliterated):}

1. Bakhrakh D.N. Administrativnoe pravo Rossii. M.: Eksmo, 2010.607 s.

2. Dvoryak A.I. Mery administrativno-protsessual'nogo presecheniya, primenyaemye militsiei. M., 1997.

3. Dugenets A.S. Administrativno-yurisdiktsionnyi protsess: Monografiya. M.: Infra-M, 2003. S. 143.

4. Il'yashenko A.N. Arest kak mera gosudarstvennogo prinuzhdeniya: teoreticheskie i istoricheskie aspekty // Obshchestvo i pravo. 2008. N 2. S. 7.

5. Kostennikov M.V., Kurakin A.V. Aktual'nye problemy administrativno-pravovogo regulirovaniya. M.: Maroseika, 2010. T. $1.496 \mathrm{~s}$.

6. Kurakin A.V. Aktual'nye problemy nauki administrativnogo prava. M.: Maroseika, 2011. 573 s.

11 См.: Дворяк А.И. Меры административно-процессуального пресечения, применяемые милицией: Дис. ... канд. юрид. наук. М., 1997. С. 147-148.

12 См.: Попугаев Ю.И. Административно-процессуальные меры, применяемые в связи с совершением правонарушения (по материалам деятельности советской милиции): Дис. ... канд. юрид. наук. М., 1991. С. 91-92. 


\section{Административное и муниципальное право 12 (84) 2014}

7. Pomogalova Yu.V. Administrativnoe zaderzhanie, dostavlenie i privod v sisteme mer administrativnogo prinuzhdeniya. Saratov. 2005.

8. Popugaev Yu.I. Administrativno-protsessual'nye mery, primenyaemye v svyazi s soversheniem pravonarusheniya (po materialam deyatel'nosti sovetskoi militsii). M., 1991.

9. Sokolov A.Yu. Mery obespecheniya proizvodstva po delam ob administrativnykh pravonarusheniyakh v sisteme mer administrativnogo prinuzhdeniya. Saratov, 2012.

10. Tyurin V.A., Kurakin A.V. Mery administrativnogo presecheniya // Yurist. 2001. № 10. S. 63.

11. Kupreev S.S. Pravovaya otvetstvennost' gosudarstva pri primenenii mer obespecheniya proizvodstva po delam ob administrativnykh pravonarusheniyakh // Administrativnoe i munitsipal'noe pravo. - 2010. - 4. - C. 70 - 75. 